\title{
Occupational Stress on Employees' Performance among National Union of Road Transportation Workers in Ilorin Metropolis, Nigeria
}

\author{
OLUSESI, Lateef Damilare \\ Department of Industrial Relations and Personnel Management, \\ Faculty of Management Sciences, \\ University of Ilorin, Ilorin, Nigeria \\ E-mail: Olusesidamilare2016@yahoo.com \\ ABDULAZEEZ, Abdulmaleek Olawale \\ Department of Human Resource Development, \\ Faculty of Management Sciences, \\ Osun State University, Osogbo, Nigeria \\ E-mail: Folorunsho111@yahoo.com \\ AJIMOTOKAN, Abidemi Eniola \\ Department of Human Resource Development, \\ Faculty of Management Sciences, \\ Osun State University, Osogbo, Nigeria \\ E-mail: Ajimotokaneniola@gmail.com
}

Received: May 2, 2020 Accepted: May 22, 2020 Online published: June 2, 2020 doi:10.5296/ijhrs.v10i2.16939ＵRL: https://doi.org/10.5296/ijhrs.v10i2.16939

\begin{abstract}
Stress has been denoted has a state of mental or emotional draining or tension consequential from adverse or demanding circumstances. The study has investigated the influence of
\end{abstract}


occupational stress on employees' performance among national union of road transportation workers in Ilorin Metropolis, Kwara State, Nigeria. The objectives of the study are to examine the influence of occupational stress (time pressure, workload, lack of motivation and role ambiguity) on employees' performance. The study population consists of random selection of commercial drivers in Ilorin Metropolis. A structured questionnaire was administered to the commercial drivers to solicit their options on the variable concerned. A total number of 200 questionnaire are administered but only 171 questionnaires were fully filled representing $86 \%$ response rate. The structured questionnaire includes the demographic information's and statements to measure the four independent variable examined on employees' performance. Linear regression analysis was carried out to examine the dependent and independent variables using SPSS. The hypotheses revealed that that time pressure and role ambiguity have significant and negative influence on employees' performance while the two other variables of workload and lack of motivation do not have any significant influence on employee performance. Therefore, it was concluded that increasing time pressure and role ambiguity would reduce employees' performance in all aspects. Therefore it is important for managers to ensure role ambiguity is minimized and clear roles are given and communicated to the employees if they wish to enhance employees' performance. Government should encourage the use of ministry of transportation (MOT) for testing vehicles; this will force and compel the owners to maintain their vehicles as adopted by UK government. Also government should provide good road facilities and good road networks.

Keywords: occupational stress, time pressure, workload, role ambiguity, lack of motivation and employees' performance

\section{Introduction}

Occupational stress can be well-defined as the injurious bodily and emotional responses that occur when the necessities of the job do not match the capabilities resources or the employees. It is also important because of its influence on our day-to-day activities and the society as a whole. It is unlikely that a person experiencing constant stress on the job will function effectively in his or her others roles. It is careful to be a person psychological state which has to do with the person's perception of the work environment and the moving practice of it.

Michi, (2002) define stress has a psychological and physical state that results when the resources of the individual are not sufficient to cope with the demands and pressures of the situation. Stress can also be describe as a physical, chemical or emotional feature that causes bodily and mental tension and may be a feature in disease causation. The reaction from brain recognizes a threat, when the threat is perceived, the human body system releases hormones that activate its "fight or flight" response.

Lawrence, (1995) established that stress is a major problem which challenges for the administrations in managing work stress in order to reduce health-care costs and improve performance in the organization. Ratnawat and Jha, (2014) also complement that the stress has become a challenge for the employer organizations as it results in low productivity, increased absenteeism and collection of other employee problems (Meneze, 2005). Seibt et 
al., (2008) cited in Ratnawat and Jha, (2014) stated that stress is always present among workers however it can be reduced by improving the working conditions and quality of benefits in the companies.

The study seeks to fill the gap of occupational stress such as time Pressure, workload, role ambiguity and lack of motivation on employees' performance among National Union of Road Transportation Workers in Ilorin Metropolis, Nigeria.

\section{Statement of the Problem}

The challenges confronting occupational stress are in varied dimensions. However, government effort cannot be sufficient in combating all these challenges. In view of this, capable researchers and students have undertaking the responsibility of exploring external opportunity in complementing the effort of the government on transportation sector. Among the problems confronting Nigeria in particular is the high rate of occupational stress especially from public and private jobs. The reason for this is not far-fetched as an unending battle on poor workplace atmosphere, job standards and decreased performance.

\section{Research Objectives}

- To examine the effect of time pressure, workload, lack of motivation and role ambiguity on employees' performance.

\section{Research Hypothesis}

- There is a significant influence of time pressure, workload, lack of motivation and role ambiguity on employees' performance.

\section{LITERATURE REVIEW}

\section{Theoretical Review}

\section{Cybernetic Theory}

The theory of occupational stress was cited by Cummings and Cooper (1979), the theory incorporates some chronological series of happenings that ensue in the stress process. This theory recommends that behaviours are directed towards goal stated, and that deviations from this can cause drain by the mechanism of mismatch between a person's actual and preferred states. The process of this theory involves detection of deviation, selection of possible adjustment processes, and implementation of processes (i.e. coping) and then the outcome effect (Cooper, Dewe, \& O'Driscoll, 2001). The research by Edwards (1992, cited in Sonnentag \& Frese, 2003) developed a related and more rigidly structured in Cybernetic theory, where it was proposed that an input was provided by the individual's state or features of the environment, then a reference value follows, based on desires, values, and goals, and then a "comparator" compares the input function with the reference value, followed by output functions (behaviours activated by discrepancies between input and reference values). In view of this, Sonnentag and Frese (2003) state that cybernetic theory remain largely empirically unsupported. 


\section{Macrothink}

\section{Interactional theories}

The interactional theories developed by Cox, Griffiths, and Rial Gonzalez, (2000) citied in (Dollard, 2003) state that interactional or transactional theory of workers stress focal point on the structural features of the person's interface with their work environment. Fundamental input-output or stimulus-response approaches was cited by early researchers, whereby the scale to which major life events or features of work design predicted a negative outcome be it, psychological, physiological or behavioral (Jones \& Kinman, 2001). Hart \& Cooper, (2001) examine the relationship between stressors and strain is consideration to be causal. By and large, much of the researches focus on sensing various worker stressors and examining their relationship to diverse guides of nervous tension, including measuring individual and organizational factors that might restrain this relationship.

\section{Conceptual Framework}

Based on the conceptual framework, below model was developed by the researcher which show the dependent variable and independent variables.

\section{Occupational Stress}

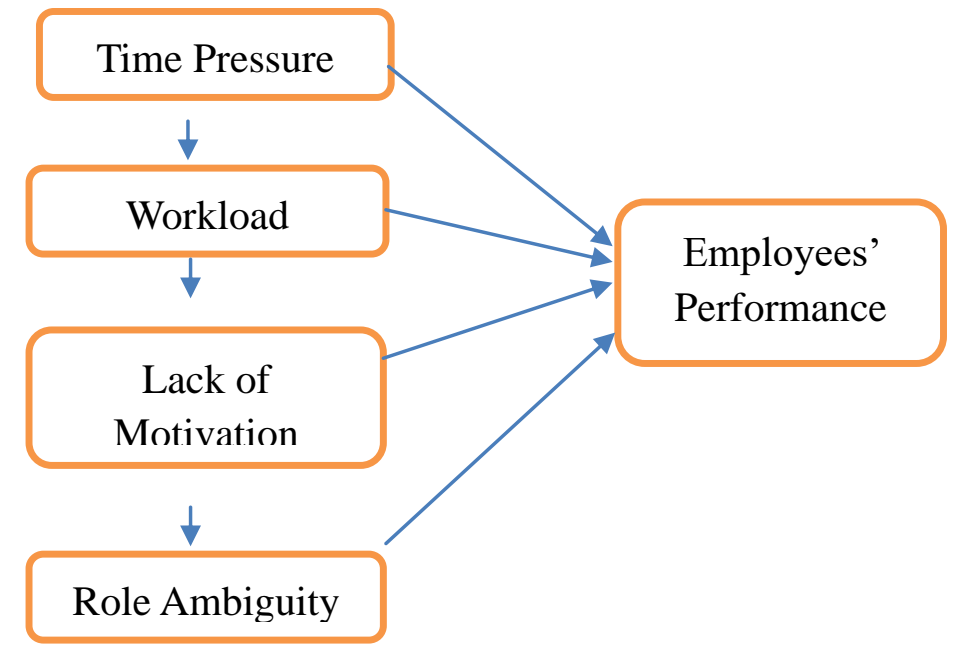

Source: Authors’ Design

Time Pressure: This is known as a psychological stress that occurs when an individual has less time available than is necessary to complete a task or to obtain a result.

Workload: Number of dissimilar roles an individual has to complete can lead to extreme demands on the individual's demanding time and may create doubt about the ability to do their roles adequately.

Lack of Motivation: This is a symptom of depression caused by difficulties in coping or taking actions.

Role Ambiguity: This is refers to as the degree to which workers are short of clarity bout their role or the task stress in the organization. Role ambiguity occurs when worker's does not realize the prospect and demands of the job. 


\section{Occupational Stress and Employees' Performance}

Jimoh, (2019) the study aimed to establish the effects of stress on employee's commitment a case study of Kwara State Internal Revenue Service. Descriptive survey research design was adopted for the study. The study population was 320 staff of the company and Yaro Yamane formula was used to arrive at 178 sample size. Questionnaire was used to gather data from the population and the data was analysed through regression analysis. The study concluded that stress had a negative effect on productivity at Kwara state internal revenue service and recommended that measures be put in place to help employees of Kwara state internal revenue service manage and reduce stress on their work.

Moaz (2016), examined the impact of stress on job performance and the purpose of his study is to determine the levels of job stress among the academic staff at Dhofar University, by measuring job performance level and the impact of the job stress factors such as workload, role conflict and role ambiguity on job performance. 102 questionnaires were administered and collected from academic staff respondents of the Dhofar University, Sultanate of Oman. The results obtained with the use of Regression analysis shows that the level of academic staff of job stress was medium and sometimes low. However, the level of job performance among academic staff was high. Furthermore, workload was tested positively on job performance. While, role conflict has negatively effect on job performance. The results shows that role ambiguity does not significantly affect job performance.

Tulsie, (2015) in his study, work stress and its effect on employees' performance in the banking sector explained that workplace stress has been shown to have a detrimental effect on health and wellbeing of the workers, as well as a negative impact on organizational productivity. Some of the reasons of occupational stress could be the inability to meet out the demands of the job, mismatch with job profile, job insecurity, relationship with colleagues and other organizational structural factors. Globally, employees undergo high level of occupational stress, grater obstruction, job dissatisfaction and complex job expectations. There are measures that individuals and organizations can take to alleviate the negative impact of stress, or to stop it from arising in the first place.

Tulsie, (2015) evaluates empirically the impact of occupational stress on employees' performance in banks. For present study, the sample was collected from Banks of major cities of Rajasthan State. Relevant data were collected through structures questionnaire. The Z-test was used to analyse the hypothesis. It was observed that occupational stress brings about idiosyncratic effects such as fear, anger, and anxiety among workers which results to poor mental and wellbeing of the employees. Based on these findings, it was recommended that banks should reduce psychological strain, job insecurity, and clear role ambiguity, through job redesign. Other support activities such as behavioural and psychological counselling and short term courses on time management and workshop on stress management can be organized.

Murtaza, Sharifa, and Nang, (2015) the study was to examine the causes and prevention of occupational stress. There are causes like atmospheres, organizational climate, and a conflict arises from work. Physical symptoms of stress include fatigue, increased blood pressure, rapid heart rate, dizziness, headaches, jaw pain, back pain, inability to concentrate and 
confusion, immunosuppression and chronic pain. They concluded that psychological disorders may lead to poor work performance, higher absenteeism, less work productivity even injury.

Ratnawat and Jha, (2015) the purpose of the investigation is to determine the impact of job related stress on employee performance. Negative stress affects the physical and mental health of the workers that in turn affects their performance on and off the job. Jex, (1998) research into the relationship between stress and job performance which was neglected in the occupational stress. It is therefore significant to understand different Occupational Stress Inducers (OSI) on one hand and their impact on different aspects of job performance on the other. Literature help us to understand the phenomenon so as to develop stress management strategies to not only save the employees from variety of health problems but to improve their performance and the performance of the organization. A model was proposed for the study to examine the impact of stress on employee job performance.

\section{Methodology}

Descriptive design was adopted for the study. Surveys are used to study to vastly populated areas where the entire population cannot be studied. The instrumentation is the process of developing, testing, and using measurement devices such as survey and questionnaire. The target population for the study comprises all drivers in Ilorin Metropolis, Ilorin, Kwara State. Simple random sampling technique was adopted. A total number 200 respondents was chosen from the registered book of the student union government, University of Ilorin. $85 \%$ of the respondent were chosen as the sample size, 171 respondent were considered for the study. A questionnaire with Likert Scale of 1-5 was developed using past literature. The construct has twenty-six (26) items measuring the following questions to collect views of respondents on Employee performance (dependent variable), Workload (independent variable), Time Pressure (independent variable), Lack of Motivation (independent variable) and Role ambiguity (independent variable). Reliability of the research instrument were tested using Cronbach Alpha at 0.70. Questionnaires were filled and returned for data analysis using Statistical Package for Social Sciences (SPSS) software, Linear Regression Analysis was used to analysis the hypotheses stated.

\section{PRESENTATION OF RESULT}

Table 1. Socio-demographic Characteristics of the Respondent

\begin{tabular}{|l|l|l|l|}
\hline Variable & Socio-Economic Variables & Respondents & Percentage \\
\hline \multirow{3}{*}{ Gender } & Male & 156 & 91.23 \\
\cline { 2 - 4 } & Female & 15 & 8.77 \\
\cline { 2 - 4 } & Total & $\mathbf{1 7 1}$ & $\mathbf{1 0 0}$ \\
\hline
\end{tabular}




\begin{tabular}{|c|c|c|c|}
\hline \multirow[t]{5}{*}{ Age Group } & Under 25yrs & 13 & 7.60 \\
\hline & $26-35 \mathrm{yrs}$ & 38 & 22.20 \\
\hline & $36-45 y r s$ & 61 & 35.70 \\
\hline & 46yrs and above & 59 & 34.50 \\
\hline & Total & 171 & 100 \\
\hline \multirow{4}{*}{$\begin{array}{l}\text { Marital } \\
\text { status }\end{array}$} & Single & 51 & 29.82 \\
\hline & Married & 95 & 55.56 \\
\hline & Divorced & 25 & 14.62 \\
\hline & Total & 171 & 100 \\
\hline \multirow{5}{*}{$\begin{array}{l}\text { Education } \\
\text { Qualification }\end{array}$} & SSCE/GCE & 78 & 45.6 \\
\hline & $\mathrm{OND} / \mathrm{NCE}$ & 52 & 30.40 \\
\hline & $\mathrm{HND} / \mathrm{BSC}$ & 41 & 24.0 \\
\hline & ACA/MBA/MSC/PhD & 0 & 0 \\
\hline & TOTAL & 171 & 100 \\
\hline
\end{tabular}

Source: Author's Fieldwork, (2020)

The characteristics of the respondents in Table 1 reveals that $156(91.23 \%)$ of the respondents were male while $15(8.77 \%)$ were female. It was revealed that $13(7.60 \%)$ of the respondents were under $25 \mathrm{yrs} ; 38(22.20 \%)$ were within age bracket 26-35yrs; 61(35.70\%) of the respondents were within age bracket 36-45yrs. while 59(34.50\%) of the respondents were within age bracket 46yrs and above. $51(29.82 \%)$ of the respondents were single; $95(55.56 \%)$ were married; $25(14.62 \%)$ of the respondents were divorced. $78(45.6 \%)$ of the respondents were holders of SSCE/GCE; 52(30.40\%) were holders of NCE/OND; 41(24.0\%) were holders of $\mathrm{HND} / \mathrm{BSC}$, while $0(0 \%)$ were holders of $\mathrm{ACA} / \mathrm{MBA} / \mathrm{MSC} / \mathrm{PhD}$.

\section{Test of Hypotheses}

The hypothesis stated that time pressure, workload, lack of motivation, role ambiguity has a significant influence of employees' performance. 
Table 2. Model Summary

\begin{tabular}{|c|l|l|l|l|l|c|c|c|c|}
\hline Model & $\mathbf{R}$ & $\begin{array}{l}\mathbf{R} \\
\text { Square }\end{array}$ & $\begin{array}{l}\text { Adjusted } \\
\mathbf{R} \\
\text { Square }\end{array}$ & $\begin{array}{l}\text { Std. } \\
\text { Error of } \\
\text { the } \\
\text { Estimate }\end{array}$ & $\begin{array}{l}\text { R } \\
\text { Square } \\
\text { Change }\end{array}$ & df1 & df2 & $\begin{array}{l}\text { Sig F } \\
\text { Change }\end{array}$ & $\begin{array}{l}\text { Durbin } \\
\text { Watson }\end{array}$ \\
\hline 1 & 0.581 & 0.336 & 0.318 & -0.6523 & 16.703 & 2 & 169 & 0.000 & 2.035 \\
\hline
\end{tabular}

a. Predictors:(constant), role ambiguity, workload, lack of motivation, time pressure

b. Dependent Variable: Employee Performance.

Table above 2 , $\mathrm{R}$ square is 0.338 , which shows that 33.8 percent of the dependent variable is being explained by independent variables. Adjusted $\mathrm{r}$ square is 0.318 which shows that a model is not a good fit model as the value is lower than 0.60. According to Imna and Hassan (2014), a good fit model would be expected to envisage a minimum of 60 percent of the variation from employee productivity (dependent variable). The Durbin Watson value is 2.035, which shows that there is no auto correlation among the selected respondents for this study as the value falls in a range of 1.5-2.5 (Folarin \& Hassan, 2015). Similarly, the F test that has been done for this study, shows the value of 16.703 , which means the regression model is significant.

Table 3. Beta Coefficient - Occupational Stress and Employees' Performance

\begin{tabular}{|l|c|c|c|c|c|}
\hline \multirow{2}{*}{ Model } & \multicolumn{2}{|c|}{$\begin{array}{c}\text { Unstandardized } \\
\text { Coefficients }\end{array}$} & $\begin{array}{c}\text { Standardized } \\
\text { Coefficients }\end{array}$ & \multirow{2}{*}{ t } & \multirow{2}{*}{ Sig. } \\
\cline { 2 - 5 } & $\mathbf{B}$ & Std. Error & Beta & & \\
\hline 1 (Constant) & 5.5649 & 0.410 & & 13.779 & 0.000 \\
Time Pressure & -0.296 & 0.119 & -0.257 & -2.484 & 0.014 \\
Workload & -0.167 & 0.115 & -0.126 & -1.459 & 0.147 \\
Lack of Motivation & 0.034 & 0.119 & 0.029 & 0.284 & 0.777 \\
Role Ambiguity & -0.307 & 0.077 & -0.370 & -4.002 & 0.000 \\
\hline
\end{tabular}

Table 3 above, time pressure beta coefficient value is -0.257 with a significant value of 0.014 which is lesser than 0.05 . In this case, time pressure has a negative significant influence on employee performance. Workload's beta coefficient value stands at -0.126 with a negative insignificant value 0.147 which is higher than 0.05 . In this case, workload is a contributor factor to stress but it is not significant. This means that workload does not have a significant influence on employee productivity. Lack of motivation's beta coefficient value from the table indicated 0.029 with a positive insignificant of 0.777 , that is higher than 0.05 . This means poor motivation does not have a significant influence on level of tress and employee performance. Role ambiguity's beta coefficient value is -0.307 with a significant value of 0.000 which is lower than 0.05 . Hence, role ambiguity has a negative and significant influence on employee performance. When employees are not sure of their role and job description in the organisation it does impact their level of productivity and contribution as 
they are not sure where they stand.

Table 4. Hypotheses Acceptance and Rejection

\begin{tabular}{|l|c|c|c|}
\hline \multicolumn{1}{|c|}{ Hypotheses } & \multicolumn{1}{|c|}{$\begin{array}{c}\text { Beta } \\
\text { Coefficient }\end{array}$} & $\begin{array}{c}\text { Significant } \\
(\mathbf{P}<\mathbf{0 . 0 5})\end{array}$ & Result \\
\hline $\begin{array}{l}\text { H1: Effect of Time Pressure towards } \\
\text { Employee Performance }\end{array}$ & -0.257 & 0.014 & Accepted \\
\hline $\begin{array}{l}\text { H2: Effect of Workload towards } \\
\text { Employee Performance }\end{array}$ & -0.126 & 0.147 & Rejected \\
\hline $\begin{array}{l}\text { H3: Effect of Lack of Motivation towards } \\
\text { Employee Performance }\end{array}$ & 0.029 & 0.777 & Rejected \\
\hline $\begin{array}{l}\text { H4: Effect of Role Ambiguity towards } \\
\text { Employee Performance }\end{array}$ & -0.370 & 0.000 & Accepted \\
\hline
\end{tabular}

\section{Discussion of Findings}

Hypothesis one which stated that there is significant influence of time pressure towards employee performance was accepted by the study, while, the influence of workload towards employee performance tested negativity by the study. The third hypothesis was also negative by the study showing the significant influence of motivation towards employee performance. While, the last hypothesis was accepted by the study proofing that there is significant influence of role ambiguity towards employee performance.

The result of hypotheses is consistent with previous study of Tulsie, (2015) which stated that workplace stress has been shown to have a detrimental effect on the health and wellbeing of employees, as well as a negative impact on workplace productivity and profits. Inability to meet demands of job is also the reasons for occupational stress. Also, there is partial similarities on the results of this study with the findings of Moaz (2016) workload has a positive statistical effect on job performance. While role conflict has negative statistical effect on job performance.

\section{Conclusion}

We, therefore, concluded that occupational stress can determine employee performance in every spare of work. The study advice the Human Resource Managers and employers in general to review their policies on occupational stress for the betterment of their employee. It was concluded that time pressure and role ambiguity has a significant adverse influence on employee performance. It is therefore, seemed that drivers' undergo job stress when they are pushed-right-to the wall and pressured to complete their task within an unreasonable time provided by their employers' or superiors. The second most influenced variable is role ambiguity. The unclear of their roles and position in their organisation does impact their job 
performance. Role ambiguity is experienced when supervisors do not deliver the right and accurate information to employees', hence this has become of the factors of occupational stress. From the survey, it clearly indicated that most of the drivers are going through predicament on where they actually stand in the organisation, where are they heading in terms of their career plans etc. As for workload and lack of motivation might not adversely impacted employee performance. It was concluded that whether employees like it or otherwise, they have to take-on the workload regardless.

\section{Recommendations}

Stress in the workplace has become the black epidemic of the present era. Stress can make an individual to be performance and constructive when it is identified and well managed. The study concluded that time pressure and role ambiguity has a significant influence on employee performance while workload and lack of motivation has no significant on employees' performance; therefore, this study recommends as follow:

i. Transportation authority should communicate and state clear roles of duties to their employee to encourage their performance.

ii. Government should encourage the ministry of transportation (MOT) for testing vehicles; this will force and compel the owners to maintain their vehicles as adopted by UK government.

iii. Government should initiate proper policies for road transport workers; good road traffic lights and signs. This will decrease the rate of accident because any accident is a stressor for every employee such as: Police issues, Accident bills and the psychological occurrence of the accident.

iv. All authorities of transportation workers should ensure well working conditions such has swift-work and avoidance of full day dirty.

\section{Reference}

Cooper, C., Dewe, P., \& O’Driscoll, M. (2001). Organizational stress. A review and critique of theory, research, and application.

Cox, T., Griffiths, A., \& Rial-Gonzalez, E. (2000) Work-related Stress. Office for Official Publications of the European Communities, Luxembourg.

Cummings, \& Cooper. (1998) in Ahmed \& Ramzan (2013) Effects of job stress on employees job performance. A study on banking sector of Pakistan, IOSR Journal of Business and Management, 11(6), 61-68. https://doi.org/10.9790/487X-1166168

Dollard, F., Winefield, R., \& Jonge, J. (2003). Psychosocial job strain and productivity in human services workers: A test of the demand-control-support model. Journal of $\begin{array}{llll}\text { Occupational and Organisational Pychology, } & 7(3), & \text { 501-510. }\end{array}$ https://doi.org/10.1348/096317900167182

Edward, K. (1992). Occupational stress and its effects on job performance. Journal of Social 
Behaviour and Personality, 6, 15-20

Hart, P., \& Cooper, C. (2001). Occupational stress: Toward a more integrated framework. Handbook of Industrial, Work and Organizational Psychology. Vol. 2: personnel Psychology). London.

Jimoh, A. (2019) Effect of stress on employee commitment: A case study of Kwara state internal revenue service. Unpublished work.

Jones, F., \& Kinman, G. (2001). Work stressors, health and sense of coherence in UK academic employees. Educational Psychology, 28(7), 823-835. https://doi.org/10.1080/01443410802366298

Lawrence, R. (1995) Managing job stress: An employee assistance/human resource management partnership, Personnel Review, 24(1), 41 - 50. https://doi.org/10.1108/00483489510079075

Menezes, M. (2005). The impact of stress on productivity at education training and development practices: Sector Education and Training Authority.

Michie, S. (2002) Causes and management of stress at work. Occupational and Environmental Medicine, 59, 67-72. https://doi.org/10.1136/oem.59.1.67

Moaz, G., Nagib, G., Syed, A., Moinuddin, A., \& Suhail, G. (2016). The impact of job stress on job performance. International Journal of Economic Research, 13(1), 21-33.

Ratnawat, G., \& Jha, P. (2014). Impact of job related stress on employee performance: A review and research agenda. Journal of Business and Management (IOSR-JBM), 16(11) 3-9. https://doi.org/10.9790/487X-161150106

Seibt, R., Spitzer, S., Blank, S., \& Scheuch, K. (2008). Predictors of work ability in occupations with psychological stress. Journal of Public Health, 1(7), 9-18. https://doi.org/10.1007/s10389-008-0194-9

Sonnentag, S., \& Frese, M., (2003). Stress in organizations. Handbook of psychology: Journal of Industrial and Organizational Psychology, 1(2), 453-491. https://doi.org/10.1002/0471264385.wei1218

\section{Copyright Disclaimer}

Copyright for this article is retained by the author(s), with first publication rights granted to the journal.

This is an open-access article distributed under the terms and conditions of the Creative Commons Attribution license (http://creativecommons.org/licenses/by/4.0/). 